\title{
Irrigation pressure vs sustenance needs of the great river Ganga (Ganges) in India with reference to Allahabad-Uttar Pradesh
}

\author{
A. Kumar \\ Department of Botany, Shyama Prasad Mukherjee Govt. Degree College, \\ Allahabad, India
}

\begin{abstract}
Ganga, a symbol of purity and plentyness of water in Indian culture and literature, is struggling for its existence today. It is mainly because of uplifting of over $80 \%$ river water for irrigation in Upper Ganga Canals responsible for yielding more than 3.55 million tons of wheat alone in western Uttar Pradesh apart from other crops like rice, sugarcane, etc. Tehri Dam, built for generation of electricity $(2400 \mathrm{MW})$, irrigation $\left(8700 \mathrm{~km}^{2}\right)$ and domestic water supply, is also limiting water flow in the river. The critically reduced water level, added with enormous amount of domestic and industrial effluents, is disquieting citizens of the country, particularly during month-long bathing festival (Kumbha Mela) of Prayag (Allahabad) in winter when water level reaches at its lowest ebb. Though the government is trying hard to regulate the discharge of untreated domestic and industrial effluents into the river, however, some age old religious practices such as throwing of the remains of various Hindu rituals, floral offerings, carcasses of certain animals, partially burnt bodies and ashes from pyres, etc. can not be controlled forcefully. Since these activities are associated with faith and sentiments, they could be countered only by motivation and awakening created under a higher religious umbrella. Our attempt is to sensitize the people against these practices by taking help of Vedas - the highest religious scriptures of the Hindus. Quotes/axioms from Vedas and related scriptures preventing water/river pollution are making great impact over the religious folks during our environmental education camps and we have come to the conclusion that apart from various pollution abatement measures, Vedic dictates are of great help in creating environmental awakening among public in general and religious
\end{abstract}


folks in particular for not to pollute water and water reservoirs, especially the great river Ganga, by their own hands.

Keywords: Allahabad, Prayag, clean Ganga campaign, Ganga and Ganga canals, Kumbh/Mahakumbh festivals, Magh Mela, river pollution.

\section{Introduction}

Ganga is a faith, more than a river with which people of India are attached to spiritually and emotionally for their psycho-religious and socio-cultural activities from time immemorial. Hindu belief holds that bathing in the river absolves human beings of all sins and helps him/her to attain salvation. People travel from distant places to immerse the ashes of their kin in Ganga to let the soul rest in peace in heaven. Needless to mention, people of India earnestly wish the river full of clean water throughout the year but at the same time, the country needs more food grains, more electricity and more water for its citizens as well. Since the western part of Uttar Pradesh, situated in the Gangetic plains, has very fertile land most suitable for the production of wheat crops, the government is under an obligation to provide the best possible irrigation facilities to the farmers of the area for which more than $80 \%$ Ganga water is lifted for irrigation purposes in Upper Ganga Canals. Likewise, Tehri Dam (a multipurpose river valley project meant for the generation of $2400 \mathrm{MW}$ electricity, irrigation stabilization to an area of $6,000 \mathrm{~km}^{2}$ at present (to be extended to an additional area of $2,700 \mathrm{~km}^{2}$ of irrigation stabilization in the future) built on the river Bhagirathi (Ganga is known as Bhagirathi before its confluence with river Alaknanda at Deoprayag in the Tehri-Garhwal district of Uttarakhand) is also responsible for the reduction of water in the river [1].

The demand of Ganga water increases enormously in winter (DecemberFebruary) each year to irrigate wheat crops. Consequently, most of the river water is lifted for irrigation during these months and the great river runs with much more concentration of domestic and industrial effluents while this is the time when the world famous Kumbh festival of Prayag (Allahabad) falls in. It is one of the most holy bathing festivals of India where pilgrims/devotees from every nook and corner of the country and abroad congregate for having a holy dip in the river. The poor religious people, mostly uneducated rural masses, take a bath in the river for redemption from their sins, but virtually, they bathe in a toxic concentrate of pollutants. This condition is agitating social organizations, religious heads and the common men of the country for raising their voice against the quality and quantity of water available in the river Ganga. Spiritual seers and celebrities across the country are waging a battle against the misdeeds of industry and mismanagement of State machinery to save the dying river. Spiritual heads representing most of the religious groups across India have launched the 'Save the Ganga Campaign' with a strong demand of 'Awiral Ganga, Nirmal Ganga' (continuously flowing Ganga, clean Ganga) from Gangotri to Ganga Sagar, which aims to clean up the river right from its source in the Himalayas to where it drains into the Bay of Bengal. 
The government has to maintain equilibrium between both the extremes where it may not even reduce the uplifting of Ganga water required for irrigation nor ignore the public demands for clean and free-flowing water in the river. Needless to state that Ganga Canals are not only the source of agricultural prosperity in the area, but if the government reduces the uplifting of Ganga water in wheat crop season, the farmers will immediately switch over to tube wells to irrigate their crops leading to disastrous depletion of ground water in this heavily populated area [2]. In the circumstances, the only option left is to make and keep the Ganga clean with whatever water is available in it after lifting the water required for irrigation.

\section{Major canals uplifting Ganga water for irrigation}

The two main canal systems viz. Upper Ganga Canals and Lower Ganga Canals drastically reduce water level in the river reaching Allahabad (Prayag). After having a long journey in the Himalayas and collecting water from its tributaries in the hills, Ganga enters in its gangetic plains at Haridwar where much of its water is lifted in Upper Ganga Canals. Starting from Haridwar, the canal traverses Meerut and Bulandshahr and continues to Nanu in Aligarh District where it bifurcates into the Kanpur and Etawah branches. Originally constructed from 1842 to 1854 for an original head discharge of $6000 \mathrm{ft}^{3} / \mathrm{s}$, the Upper Ganges Canal has since been enlarged gradually for the present head discharge of $10,500 \mathrm{ft}^{3} / \mathrm{s}$. The system consists of main canal of 272 miles and about 4000 miles long distribution channels. The canal system irrigates nearly $9,000 \mathrm{~km}^{2}$ of fertile agricultural land in western Uttar Pradesh. Likewise, starting at Narora, Lower Ganges Canals are extended up to 5,120 miles $(8,240 \mathrm{~km})$ with its branches. A channel from a weir at Narora intersects the canal system $48 \mathrm{~km}$ downstream from Nanu, and continues past the Sengur River and Sersa River, past Shikohabad to Manpuri district to become the Bhognipur branch which was opened in 1880. This branch, starting at village Jera in Mainpuri district, runs for $166 \mathrm{~km}$ to reach Kanpur. At kilometre 64 the Balrai escape carries excess water through a $6.4 \mathrm{~km}$. channel through the ravines to discharge into the Yamuna. This branch has $386 \mathrm{~km}$. of distributary channels. The old channels of Kanpur and Etawah branches between Nanu and the point of intersection by the channel from Narora, are known as "stumps", and are utilized only when the supply of water in the lower Ganges system runs low [3].

The economics of Ganga water lifted for irrigation can be understood in terms of virtual water concept: the water that is used in the production process of agricultural or industrial products [4]. For the production of one ton of cereals in Indian conditions, 3000 tons of virtual water is required. India produces 78 million tons of wheat every year out of which 3.55 million tons of wheat is produced in western Uttar Pradesh irrigated by Ganga water through Upper Ganga Canals [5]. One can very well understand and calculate the amount and cost of water in producing 3.55 million tons of wheat every year by Ganga water in western Uttar Pradesh apart from other crops in this area. 


\section{Ganga: from myth to reality}

Since time immemorial, Hindus have always believed that Ganga water is divine in nature and has potential to cure and clean/pure body and soul of all the creatures on this planet. In Indian culture and civilization, Ganga has acquired the status of a mother Goddess and synonym of all the rivers in which plenty of pure water is flowing round the year. Likewise, 'Ganga Jal' has become the synonym of pure, Pavitra (pious) and drinkable/potable water. Hindus attach so much reverence to the Ganga water that no Hindu rituals, from birth to death, cannot be consecrated without Ganga water.

In 1896, Hanbury Hankin (a British Physician) after testing the water of Ganga wrote in a paper published in the French Journal 'Annales de Institut Pasteur' that the bacterium Vibrio Cholerae which causes the deadly cholera disease, when put into Ganga water died within three hours. The same bacterium continued to thrive in distilled water even after 48 hours. Likewise, in 1927, Flix dHerelle, a French microbiologist, was amazed when he saw that only a few feet below the bodies of persons floating in the Ganga who had died of dysentery and cholera, where one would expect millions of germs, there were no germs at all. Hindus had for thousands of years rightly believed that Ganga purifies the dead bodies, which is why probably the bodies of even those who died of infectious diseases were offered to this river for purification [6].

The presence of bacteriophages in Ganga water is one of the reason behind its purity (Bacteriophages are those viruses which kill bacteria through transduction and during this process they increase their population by consuming the cell contents of the victim bacteria). In fact what Hankin reported in 1896 about the antibacterial nature of Ganga was the first modern observation/documentation of the presence of bacteriophages in the Ganga water. It was Herelle, (who again observed the anti-bacterial nature of Ganga) coined the term Bacteriophage (meaning bacteria eater) for these viruses. The waters of Ganga when added to other water resources in adequate amount, causes the bacteriophage in it to quickly multiply cleaning the new water resource of any bacteria present in it. Today more and more bacteria are becoming resistant to antibiotics and the bacteriophage therapy could be a potential alternative of the latter. GangaGen Biotechnologies, a bio-medical research company based at Bangalore, is now working on the alternative therapy of bacteriophage based treatment for antibiotic resistant bacteria. It is the first firm that have developed bacteriophage based commercial products. Their first bacteriophage based product was to treat the problem of E. Coli in Cattle [6].

Though the original Ganga water coming from Himalaya full of bacteriophages and medicinal values are now lifted in canals and the river runs filled with various industrial effluents and domestic sewerage, even then, whatever water is left in the river shows the character of bacteriophage activity. It is evident from the fact that millions of devotees bathe in highly polluted Ganga during Kumbh/Mahakumbh festivals but never any epidemic by water borne diseases in them have appeared due to bathing in the Ganga. Perhaps, it is partly because of the presence of bacteriophages and partly because of the 
occurrence of an innumerable number of medicinal plants in the catchment areas of the high altitude Garhwal Himalayas from where Ganga collects its precious water before entering into the Gangetic plains.

The high level of oxygen in Ganga water also gives the river a unique ability to remain fresh over a prolonged period of time. It has been worked out that Ganga is able to reduce its biochemical oxygen demand levels much faster than other rivers. The self-purifying ability of this river leads to oxygen levels that are 25 times higher than any other river in the world. Ganga cleans up suspended wastes 15 to 20 times faster when compared to other rivers because it is rich in polymers excreted by various species of bacteria. These polymers being excellent coagulants remove turbidity by coagulation, setting the suspended particles even at the sewage discharge points [7].

Not only Hindus, but the British and Mughals in the past also recognized this supernatural power of Ganga water. The great emperor Akbar called Ganga water the 'water of immortality' and always travelled with a supply. The British East India Company used only Ganga water on its ships during the three-month long journey back to England, because it stayed 'sweet and fresh' [8].

\section{Ganga at Allahabad}

Allahabad, popularly known as Prayag, situated at the confluence (Sangam) of two great rivers Ganga and Yamuna (and the third mythical river Saraswati), is a pilgrim place, sacrosanct and of great international fame because of congregation of world famous Kumbh festivals (Magh Mela) in winter each year and Ardha Kumbha and Mahakumbh at an interval of 6 and 12 years, respectively. Millions of pilgrims assemble on the bank of these rivers during Kumbh/ Ardhkumbh/ Mahakumbh festivals. Apart from that, a large number of devotees popularly known as 'Kalpavasi' stay here in thousands and thousands of makeshift tents on the banks of river Ganga during winter every year. The Mahakumbha continues to be a rarest event in the history of India in terms of the assembly of around 20 million devotees who gather here for a holy dip. The next Mahakumbh is scheduled in 2013 during which around 25 million pilgrims are expected to reach here. It is obvious that clean and sufficient water flow is required in the Ganga at least during Mahakumbh 2013.

\section{Ganga pollution at Allahabad}

Ganga reaches Allahabad collecting large amount of domestic and industrial effluents from cities and towns situated along its banks, especially from Kanpur $[9,10]$, and becomes more polluted after receiving 230 mld sewerage from Allahabad township. In the year 1986, only 110 mld sewage was being discharged in the river Ganga and Yamuna at Allahabad which increased to 210 mld in 1998-99 and is expected to reach 260 mld by the year 2015 and 332 mld by the year 2035 [11]. At present in the year 2010, on an average $230 \mathrm{mld}$ sewage is being poured in the Ganga and Yamuna collected through 45 main drains as shown in table 1, and 12 small drains viz. Fort Drain No. 1 and 2, 
Table 1: $\quad$ Average sewer collected from Allahabad township.

\begin{tabular}{|c|c|c|c|}
\hline S. No. & Drain No. & Nala Name & CuM per day \\
\hline 1. & 01 & Ghaghar Nala Main & 40000 \\
\hline 2. & $1 \mathrm{~A}$ & Ghaghar Nala 1-A & 4,000 \\
\hline 3. & 1B & Ghaghar Nala 1-A-1 & 200 \\
\hline 4. & $1 \mathrm{C}$ & Ghaghar Nala 1-B & 750 \\
\hline 5. & $1 \mathrm{D}$ & Dariabad Kat-Har Ghat Nala & 100 \\
\hline 6. & $1 \mathrm{E}$ & Dariabad Pipal-Ghat Nala & 30 \\
\hline 7. & $1 \mathrm{~F}$ & Dariabad Dhobi-Ghat Nala & 50 \\
\hline 8. & 02 & Chachar Nala & 34000 \\
\hline 9. & 03 & Emergency Nala & 15250 \\
\hline 10. & 04 & Gate No. 9 Drain & 200 \\
\hline 11. & 05 & Gate No. 13 Drain & 4000 \\
\hline 12. & 07 & Mori Gate Nala & 38840 \\
\hline 13. & 08 & Dara Ganj Drain & 3000 \\
\hline 14. & 10 & Salori Nala $(+09)$ & 27100 \\
\hline 15. & 11 & Jodhwal Nala & 2500 \\
\hline 16. & $11 \mathrm{~A}$ & Sankarghat Nala & 200 \\
\hline 17. & $11 \mathrm{~B}$ & Rasulabad Puccka-Ghat Drain & 40 \\
\hline 18. & $11 \mathrm{C}$ & ADA Colony Nala & 1000 \\
\hline 19. & $11 \mathrm{D}$ & Jondhwal Rasulabad Drain (Murdaghat) & 70 \\
\hline 20. & $11 \mathrm{E}$ & Sankarghat Colony Drain & 10 \\
\hline 21. & $11 \mathrm{~F}$ & Jodhwal Ghat Drain & 70 \\
\hline 22. & 12 & Rajapur Nala & 7000 \\
\hline 23. & $12 \mathrm{~A}$ & TV Tower Nala & 2000 \\
\hline 24. & $12 \mathrm{~B}$ & TV Tower Nala 2 & 3000 \\
\hline 25. & $12 \mathrm{C}$ & Unchawagarh Drain I & 700 \\
\hline 26. & $12 \mathrm{D}$ & Unchawagarh Drain II & 250 \\
\hline 27. & $12 \mathrm{E}$ & Beligaon Drain & 250 \\
\hline 28. & $12 \mathrm{~F}$ & Mumfordganj Drain & 400 \\
\hline 29. & $12 \mathrm{G}$ & Muirabad (Ganesh Nagar) Nala & 1000 \\
\hline 30. & $12 \mathrm{H}$ & Naya Purwa Drain & 80 \\
\hline 31. & 12I & Mehdauri Gaon Drain & 200 \\
\hline 32. & 13 & Mawaiya Nala & 9000 \\
\hline 33. & 14 & Shivkuti Drain No.1 & 20 \\
\hline 34. & $14 \mathrm{~A}$ & Shivkuti Drain No.2 & 10 \\
\hline 35. & $14 \mathrm{~B}$ & Shivkuti Drain No.3 north & 1000 \\
\hline 36. & $14 \mathrm{C}$ & Shivkuti Drain No.4 & 10 \\
\hline 37. & 14D & Shivkuti Drain No.5 & 30 \\
\hline 38. & $14 \mathrm{E}$ & Shivkuti Drain No.6 & 20 \\
\hline 39. & $14 \mathrm{~F}$ & Shivkuti Drain No.7 east & 720 \\
\hline 40. & 18 & Indira Awas Nala & 230 \\
\hline 41. & 20 & Lutere Nala & 2000 \\
\hline 42. & 21 & Shastri Bridge Nala & 20 \\
\hline 43. & 22 & Kodhar Nala & 6700 \\
\hline 44. & 23 & Nehru Park Nala & 500 \\
\hline 45. & 24 & Pon-Ghat Nala & 1700 \\
\hline
\end{tabular}


Allenganj Drain, Chilla Drain, Govindpur Colony Drain, Govindpur Colony Drain Purani Basti, Govindpur Drain No 1, 2 and 3, Cooperative Nala, Basna Nala and Shivpur Nalas [12]. Disposing human remains and submerging dead bodies of young babies and persons succumbed to unnatural deaths, etc for various religious reasons are degrading quality of water to a hazardous level. Nevertheless, for more than two decades, chemistry of Ganga water at Allahabad has not much changed. In the year 1986, the Biological Oxygen Demand (BOD) and Dissolved Oxygen (DO) levels (the two parameters taken into account to measure health of a reservoir) in down stream river water were $15.5 \mathrm{mg} / \mathrm{l}$ (against recommended level of $3 \mathrm{mg} / \mathrm{l}$ or less) and $6.6 \mathrm{mg} / \mathrm{l}$ (against recommended level of $5 \mathrm{mg} / \mathrm{l}$ or more), respectively. In the year 2005, maximum BOD was $14.6 \mathrm{mg} / \mathrm{l}$ and minimum was $10.9 \mathrm{mg} / \mathrm{l}$ whereas, minimum DO was $3.4 \mathrm{mg} / \mathrm{l}$ and maximum was $6.7 \mathrm{mg} / \mathrm{l}$. [13].

According to the Central Pollution Control Board of India, fresh water has been divided into 5 categories. Category A represents drinking water source without conventional treatment but after disinfection. Total coliform organism should be 50 or less in each $100 \mathrm{ml}$ of sample, DO $6 \mathrm{mg} / \mathrm{l}$ or more and BOD 2 $\mathrm{mg} / \mathrm{l}$ or less. Category B represents water suitable for outdoor organized bathing. It should have total coliforms organism 500 or less in each $100 \mathrm{ml}$ of sample, DO $5 \mathrm{mg} / \mathrm{l}$ or more and BOD $3 \mathrm{mg} / \mathrm{l}$ or less. Category $\mathrm{C}$ denotes drinking water source after conventional treatment and disinfection and should have total coliforms 5000 or less in each $100 \mathrm{ml}$ of sample, DO $4 \mathrm{mg} / \mathrm{l}$ or more and BOD 3 $\mathrm{mg} / \mathrm{l}$ or less. Category D could be used only for propagation of wild life and fisheries whereas the category $\mathrm{E}$ is unsuitable for domestic uses and could be utilized only for irrigation and industry [14]. Unfortunately, except during monsoon when river is flooded with water, category of Ganga water in Allahabad remain even below the Category ' $\mathrm{E}$ '.

In the year 1980, World Health Organization (WHO) recommended certain treatment yardsticks before pouring domestic sewage and industrial effluents into water bodies and for its utilization for irrigation purposes. As per WHO recommendations, irrigation of crops to be eaten raw with treated wastewater only after it has undergone biological treatment and disinfection to achieve a coliform level of not more than 100/100 ml [15]. However, based on epidemiological evidence, WHO came out with alternate guidelines recommending faecal coliform levels less than $200 / 100 \mathrm{ml}$. for irrigation of sports fields, public parks, hotel, lawns and less than 1000/100ml. for irrigation of crops likely to be eaten raw [16]. As per report of the Ganga Pollution Control Unit, Allahabad, the govt machinery responsible for sewage treatment of Allahabad township, the total treatment capacity is just $89 \mathrm{mld}$ against the daily sewerage discharge of $230 \mathrm{mld}$ [17].

\section{Government's attempts in making the river clean}

For the last two and half decades, the government of India is trying hard to make the river clean, and to achieve the goal launched Ganga Action Plan (GAP-I) in 1985. The plan was extended as GAP-II from 1993 covering 4 major tributaries 
of Ganga namely Gomti, Yamuna, Damodar and Mahananda. The programme was further expanded in the year 2000 and was renamed as National River Conservation Plan (NRCP) covering 34 rivers and 160 towns in 20 States of the country. Till 2006, a massive grant of Rs 47,350 million INR was approved for NRCP [18]. On November 4, 2008 Government of India declared Ganga as 'National river' and set a high powered National Ganga River Basin Authority (NGRBA) on 20 February 2009 under the chairmanship of the Prime Minister of India with multipronged approach including water quality, minimum ecological flows, sustainable access and other issues relevant to river ecology and management. For Allahabad, Under Ganga Action Plan Phase I, Rs 407.711 million and during GAP Phase II, Rs 344.89 million was sanctioned by the government. A special grant of Rs 6403.50 million was also approved under JICA (Japan International Cooperation Agency) programme to improve the pollution abatement facilities at Allahabad, Kanpur and Varanasi. Now the State Government of Uttar Pradesh has also set a 'Uttar Pradesh State Ganga River Basin Authority (UPSGRBA) and has demanded Rs 16000 million for Kanpur, Rs 4940 million for Varanasi and Rs 3360 million for Allahabad from NGRBA [19].

The Govt of India has reasons to believe that by 2020 the polluted River Ganga would be cleaned and to this end, has committed to spend Rs 1500 million for the purpose. On December 2, 2009, World Bank has also committed India to provide $\$ 1$ billion as assistance for cleaning up the heavily polluted Ganga from Gangotri to Ganga Sagar [20]. The Cabinet Committee on Economic Affairs (CCEA) held on 23 April, 2010 approved sewerage and nonsewerage schemes for abatement of pollution in the river Ganga at Allahabad with an estimated cost of Rs 3053.4 million [21].

\section{Public motivation for keeping the Ganga clean}

Most of the rituals of Hindus adding garbage in Ganga are having deep religious roots. Age old traditions and psycho-religious fears further drive people to deepen this problem. Consequently, it is not feasible to restrain these innocent people from discharging their socio-cultural/religious obligations towards this river. However, public motivation against rituals polluting the river without hurting their sentiments is need of the hour. Since these rituals are having religious undertones/sanctions, their prevention must also be based on higher religious dictates of scriptures of the stature of Vedas whom the Hindus hold in high esteem and submit to their dictates willingly. Quotes/ axioms cited from the scriptures / epics greatly facilitate emergence of a widely accepted code of conduct or ethics for water conservation and its judicious use. These dictates are being taken to motivate the public and to sensitise them regarding the conservation of the purity of Ganga water.

Vedas, written at least $2400 \mathrm{BC}$, uphold the significance of pure water in human life since times immemorial [22]. For instance, an aphorism from Brahmandpurana, written about 325-400 AD, says 'Ganga punyajalam prapya trayodashvivarjayet. Shauchamachamanamshekam, nirmalyam 
malagharshanam. Gatrasamvahanam krinam pratigrahamatoratim. Anyatirtha ratinchaiva anyatirthaprashanshanam. Vastratyagamaghadyatam santarnchvisheshatah', i.e. 'The thirteen acts prohibited on arrival at sacred water of Ganga are defecation, ablution, discharge of water/urination, throwing of used floral offerings, rubbing of filth, body shampooing, frolicking, acceptance of donations, obscenity, offering of inappropriate praises, discharge of garments and beating and swimming across the river'. These dictates show much impact over the audience attending our environmental awakening camps and they return home with a promise to follow these dictates willingly. Rig Veda [23] says 'Apswantar mritamapsu bhesajma yamutaprashastaye. Devabhaktivajinah' means 'pure water contains Amrit (the nectar) and is the best medicine of the world. Praise (care) pure water and be happy'. 'Yadadovat te grihe amritasya indhirhitah. Ten no dehi jeevase [24] means 'if you wish to live a happy life free from diseases, then keep your water and air pure'. 'Purvirasya nishshidho martyeshu, puruvasuni prithivibibharti. indrayaydyav aushadhirutapo, rayimraxanti jirayovanani' [25] i.e. the 'God has given us ample gift of nature. This natural wealth is imperishable provided you protect its components: the earth and its atmosphere, the trees and herbs, the water and its resources like rivers, streams, waterfalls and the forests'. Likewise, Atharva Veda [26] says 'Samanim prapasat voannabhogaga samane yoktraisah vo yunijma sabhyanchoagnim samparyatara. Namimivaamitah' means 'everyone has an equal right to get food grains and everyone is linked with one another. You all work together like the wheels of a chariot to maintain the quality of all natural resources especially the water'. During our environmental awakening camps, such moral appeals deeply influence the religious folk and help to enlighten them towards protection of water and its reservoirs, especially the great river Ganga.

\section{Conclusions}

Despite this dismal fact, the public of India and the pilgrims coming Allahabad/ Prayag have not given up their hopes, and they firmly believe that one day the Ganga will regain its pristine purity. In Indian mythology, Ganga has attained the status of mother Goddess, and is in true sense, playing the role of a mother by feeding the millions through the crops produced by its water. People must realize that uplifting of Ganga water for irrigation is meant to sustain life of millions, though at her own cost. In return, it is our duty to contribute whatever we can to keep the mother Ganga clean to enable her to satisfy our physical needs, spiritual as well.

As one of the solutions to reduce the uplifting of Ganga water without curtailing the irrigation requirements is the harvesting of rain water which could be more effective in rural areas both for recharging of ground water as well as for re-use of stored rain water in the improvised ponds for irrigation. The time has come to make it mandatory for every farmer to bring at least $10 \%$ of their lands under pond system. These ponds could be utilized for fish farming as well. More and more incentives should be given to the farmers for construction and 
maintenance of new and existing aquifers. All water reservoirs, especially the rivers, should be de-silted or cleaned up in order to increase their water holding capacity.

Renovation (cleaning, de-silting and repairing) of the existing sewers and out falls to prevent the over flows of sewage into water reservoirs should be carried out on priority basis. Throwing of used floral offerings, dead human bodies and carcasses of animals in water bodies should be discouraged and legally regulated. Pilot projects to assertain feasibility of technology applications in the treatment of domestic sewage and industrial effluents should be worked out and implemented at large scale. In all water technology uses, there must be checks for generation of waste overloads. River Ganga has better self purifying ability and capacity by which it could maintain its ecological integrity. Any over exploitive technology will break this capacity and will lead to water chaos. And therefore, rules must be framed and enforced not to overload water reservoirs from solid garbage of cities and towns. The sense of responsibility coupled with compulsion of the day in newer economic situation must be understood by all. Proper environmental awakening should be inculcated in young as they are the future citizens of the society. The environmental education must be made a compulsory component of school curriculum along with extension activities involving students as an agent of change in the community.

\section{References}

[1] Kumar, A., Sustainable water management with special reference to river Ganga at Allahabad, India. Proc. of the 'International Symposium on Community-Led Management of River Environment' eds. R. Mutschler, P.K. Shreshtha \& K.P. Sharma, Kathmandu, Nepal (ISBN: 9789937200738), pp. 78-90, 2007.

[2] Kumar, A., Sustainable water management with special reference to Ganga and Allahabad: An appraisal., Proc. of the National Seminar on Sustainable Water Management, ed. A. Kumar, SPMDC Publications, Allahabad, India. pp 425-439, 2005.

[3] Ganga Canal.: en.wikipedia.org

[4] Hockstra, A.Y. \& Hung, P.Q., Virtual Water Trade. 1 HE Value of water Report Series no: 12. Delft. 2002.

[5] India's wheat production estimated to surpass record 78 million tons. www.thaindian.com

[6] The Sacred Secrets of Ganga. www.hitxp.com

[7] Bhargava, D.S., Purification power of the Ganges unmatched. L.S.T. Bull. 34, pp. 52, 1982

[8] Mystery factor gives Ganges a clean reputation. www.npr.org

[9] Beg, K.R. \& Ali, S., Chemical contaminants and toxicity of Ganga river sediment from up and down stream area at Kanpur. American Journal of Environmental Sciences 4 (4), pp. 362-366, 2008

[10] Ganga River Pollution in India- A Brief Report by Dr Nitish Priyadarshi. 8 September, 2009., www.gangajal.org.in 
[11] Pollution abatement of river Ganga at Allahabad. Report published by U.P. Jal Nigam, Allahabad, 2006.

[12] Personal communication with Uttar Pradesh Jal Nigam, Allahabad, 2010.

[13] Srivastava, V. \& Shukla, D.N., How to sustain Ganga water around Allahabad, Proc. of the National Seminar on Sustainable Water Management. ed. A.Kumar, SPMDC Publications, Allahabad, pp 151-156, 2005.

[14] Status of water supply, wastewater generation and treatment in class-I cities and class-II towns of India. Control of urban pollution series: cops/70/200910 www.cpcb.nic.in

[15] WHO Report., Health aspects of Treated Sewage Reuse, EURO, 1980.

[16] Arceivala, S.J., Wastewater treatment for pollution control, Tata McGraw Hill, New Delhi, 1999.

[17] Dainik Jagaran (Daily News Paper), www.jagaran.com., 25 October, 2010

[18] NRCD Report., National River Conservation Directorate, Ministry of Environment \& Forest, Govt of India Publications. New Delhi, 2006.

[19] National Ganga River Basin Authority (NGRBA). Ministry of Environment \& Forests, Govt of India. www.moef.nic.in

[20] Clean Ganga, www.thaindian.com

[21] Pollution abatement scheme okayed for Ganga at Allahabad. www.netindian.in

[22] Kumar, A., Vedas and IPR: Documentation and interpretation of a few scientific observations about Sun, Earth and Environment from Vedas (Chapter 4). Biodiversity, Biotechnology and Traditional Knowledge, eds.

A. Kumar \& G. Das, Narosa Publishing House, New Delhi, (ISBN 978-81-8487-097-8) pp 22-26, 2010.

[23] Rig veda 23.19.11

[24] Rig veda 10.186.3

[25] Rig Veda 3.51.5

[26] Atharva Veda 3.30.6 